Materiales de Construcción

Vol. 69, Issue 336, October-December 2019, e203

ISSN-L: 0465-2746

https://doi.org/10.3989/mc.2019.13618

\title{
Self-activation of slag-cements with glass waste powder
}

\author{
M.A.Trezza $₫$, V.F.Rahhal \\ Facultad de Ingeniería (UNCPBA) and CIFICEN (UNCPBA-CICPBA-CONICET), Olavarría (Argentina) \\ $\triangle \mathrm{m}$ trezza@fio.unicen.edu.ar
}

\author{
Received 20 December 2018 \\ Accepted 24 June 2019 \\ Available on line 25 September 2019
}

\begin{abstract}
The aim of this study is to evaluate the behavior of glass powder waste as alkaline activator of slag when both are used in blended cement. The slag blended cement was prepared with $70 \%$ slag, and then the slag was replaced with $10-20 \%$ glass powder by mass. The self-activation concept is here introduced. Ground glass releases alkalis through dissolution in a slow and sustained way over time. This would activate slag. Ground glass improves fluidity of mortars and the compressive strength overcomes dilution and increases with age due to the combined pozzolanic action of slag and glass. The proposed blended cement has better mechanical properties than slag-cement. The proposed blended cement has better mechanical properties than slag-cement and due to less use of slag, it becomes more sustainable and it contributes to waste management.
\end{abstract}

KEYWORDS: Blended cement; Slag; Glass; Alkaline activation; Infrared spectroscopy.

Citation/Citar como: Trezza, M.A.; Rahhal, V.F. (2019) Self-activation of slag-cements with glass waste powder. Mater. Construcc. 69 [336], e203 https://doi.org/10.3989/mc.2019.13618

RESUMEN: Autoactivación de cemento de escorias con polvo de vidrio de descarte. El objetivo del presente trabajo es evaluar el comportamiento de un residuo molido de vidrio como activador interno de la escoria cuando ambos son usados en un cemento mezcla. El cemento de escoria fue preparado con un $70 \%$ de escoria y luego la escoria se reemplazó en un 10 y $20 \%$ en masa por vidrio molido. Este trabajo introduce el concepto de autoactivación. El vidrio molido libera álcalis por disolución, en forma lenta y sostenida en el tiempo que activarían la escoria. La presencia de vidrio molido mejora la fluidez de los morteros y la resistencia a compresión supera la dilución y crece con la edad por la acción puzolánica combinada de la escoria y el vidrio. El cemento mezcla propuesto tiene mejores propiedades mecánicas que el cemento de escorias pero con menor contenido de escoria por lo que es más sustentable y contribuye al manejo de residuos.

PALABRAS CLAVE: Cemento mezcla; Escoria; Vidrio; Activación alcalina; Espectroscopia infrarroja.

ORCID ID: M.A. Trezza (https://orcid.org/0000-0002-4193-0066); V.F. Rahhal (https://orcid.org/0000-0001-7710-1203)

Copyright: (C) 2019 CSIC. This is an open-access article distributed under the terms of the Creative Commons Attribution 4.0 International (CC BY 4.0) License. 


\section{INTRODUCTION}

Slag-cements appear as an alternative material to Portland cement. Although they have similar physical and mechanical properties, slag cements are more sustainable. Granulated blast furnace slag is a by- product of iron production and widely used as an active addition to Portland cement. It is classified as a latent hydraulic material with pozzolanic properties (1). When using slag at replacement ratios greater than $50 \%$, the main disadvantage is the low strength gain at early ages due to the slow hydration rate of slag. However, this behavior is reverted at later ages with better mechanical and durable properties than those of Portland cement based materials (2).

The incorporation of large volumes of slag into cement generates a less hydration product volume because of the small amount of calcium hydroxide $(\mathrm{CH})$ from the hydration of clinker, which is the chemical activator of slag. Therefore, mechanical strength that is directly related to the degree of cement hydration advancement falls, especially at early ages.

An alternative is thermal treatment, which is an effective means to accelerate slag hydration. Nevertheless, to improve strength of blast-furnace cements, the water/binder (w/b) ratio and the curing temperature should be properly designed according to the proportion of slag in cement (3).

Alkaline-activated slag-cement has been widely used since 1940s (1). Other alternative cements are alkaline-activated cements and/or geopolymers, which use $100 \%$ of their industrial by-products (e.g.,
$100 \%$ slags) with alkali activators such as sodium hydroxide, sodium silicate, and sodium carbonate.

Alkaline-activated blended cement or hybrid cement is the more recent and innovative option. This material uses a high ratio of industrial byproducts, such slag and fly ash, with less than $30 \%$ Portland cement or clinker, and the mixture is alkali activated (4 -6).

On the other hand, glass is a $100 \%$ recyclable material. It does not lose its physical properties or quality in the recycling process (7). For each ton of recycled glass, 130 kilos of fuel and 1200 kilos of raw material are saved. However, the percentage of glass recycled and reincorporated into the productive circuit is very low.

As glass is amorphous and it contains a relatively large amount of silica and calcium, it would become pozzolanic when finely ground $(8,9)$. Thus, an interesting way of reusing these wastes would be involved.

Using DTA techniques Federico et al. (10), showed that glass reactivity is similar to ground-granulated blast slag and lower than silica fume at comparable particle size. Zhang et al. (11) analyzed the feasibility of a waste glass powder residue as partial mineral precursor to produce alkali-activated materials. It was reported that, compared with powder coal fly ash, glass powder is better involved in the alkali activation process due to higher silica and Ca dissolution.

In order to extend this use, the aim of this study is to analyze the self-activation role of glass powder in the slag-glass system by the incorporation of different percentages of ground glass powder without previous treatment of slag-cement.

TABLE 1. Chemical composition and physical characteristics of materials

\begin{tabular}{|c|c|c|c|c|}
\hline Chemical composition & & $C$ & $S$ & $\boldsymbol{G}$ \\
\hline $\mathrm{SiO}_{2}(\%)$ & & 21.5 & 34.07 & 70.91 \\
\hline $\mathrm{Al}_{2} \mathrm{O}_{3}(\%)$ & & 3.8 & 11.95 & 1.55 \\
\hline $\mathrm{CaO}(\%)$ & & 64.3 & 38.58 & 10.75 \\
\hline $\mathrm{Fe}_{2} \mathrm{O}_{3}(\%)$ & & 3.8 & 1.04 & 0.26 \\
\hline $\mathrm{Na}_{2} \mathrm{O}(\%)$ & & 0.1 & 0.15 & 13.80 \\
\hline $\mathrm{K}_{2} \mathrm{O}(\%)$ & & 1.1 & 0.41 & 0.89 \\
\hline $\mathrm{SO}_{3}(\%)$ & & 2.6 & 0.84 & 0.21 \\
\hline $\mathrm{MgO}(\%)$ & & 0.8 & 9.54 & 0.10 \\
\hline LOI $(\%)$ & & 2.1 & 1.30 & 1.14 \\
\hline Physical characteristics & & $C$ & $S$ & $G$ \\
\hline Density & & 3.15 & 2.95 & 2.50 \\
\hline Absorption (\%) & & - & 0.90 & 0.40 \\
\hline Specific surface, Blaine $\left(\mathrm{m}^{2} / \mathrm{kg}\right)$ & & 315 & 460 & 609 \\
\hline \multirow{2}{*}{$\begin{array}{l}\text { Retained on } \\
\text { sieve }(\%)\end{array}$} & $75 \mu \mathrm{m}(\# 200)$ & - & 0.00 & 1.44 \\
\hline & $45 \mu \mathrm{m}(\# 325)$ & - & 0.90 & 7.98 \\
\hline \multirow[t]{3}{*}{ Particle size distribution $(\mu \mathrm{m})$} & $\mathrm{d}_{90}$ & 63.5 & 41.6 & 24.6 \\
\hline & $\mathrm{d}_{50}$ & 19.0 & 14.5 & 7.5 \\
\hline & $\mathrm{d}_{10}$ & 2.7 & 2.3 & 1.6 \\
\hline
\end{tabular}




\section{MATERIALS AND METHODS}

\subsection{Materials}

A type I ordinary Portland cement, ASTM C150 (C), a ground granulated blast-furnace slag (S) and white bottle glass $(\mathrm{G})$ powder were used to prepare blended cement for this study. The chemical composition of C, obtained by X-ray fluorescence spectrometry, is reported in Table 1 . The mineralogical composition of $\mathrm{C}$, calculated by Bogue formulas, was $\mathrm{C}_{3} \mathrm{~S}: 60 \%$, $\mathrm{C}_{2} \mathrm{~S}: 16.4 \%, \mathrm{C}_{3} \mathrm{~A}: 3.8 \%, \mathrm{C}_{4} \mathrm{AF}: 11.5 \%$. The chemical composition of $\mathrm{S}$ and $\mathrm{G}$ are also given in Table 1 and determined by Inductively Coupled Plasma Atomic Emission Spectroscopy (ICP-AES) analysis. The mineralogical composition was identified by X-ray diffraction (XRD) and FTIR spectroscopy (FTIR). XRD analysis was performed using a Philips PW 3710 diffractometer operating with $\mathrm{Cu} \mathrm{K} \alpha$ radiation at $40 \mathrm{kV}$ and $20 \mathrm{~mA}$ and the FTIR spectra were performed on NICOLET Magna 550 using $\mathrm{KBr}$ technique.

The physical characteristics of all materials (density, absorption, specific surface, retained on sieve and particle size distribution d10, d50, and d90) also appear in Table 1. According to Table 1 and Figure 1, $\mathrm{C}$ has high density and particle size distribution with large volume of particles, bigger than the $\mathrm{S}$ and the G. Glass powder has the smallest ones. Having different particle size distribution favors packaging of mixtures, reducing empty spaces and increasing packing density (12). Management of these parameters is vital to obtain more resistant and more durable concretes.

XRD (Figure 2a) analysis of $\mathrm{S}$ and $\mathrm{G}$ shows absence of crystalline compounds. Only a diffuse band in $15-40^{\circ} 2 \theta$ was observed assigned to amorphous silicate from $\mathrm{G}$ and another diffuse band centred at $2 \theta=30^{\circ}$ assigned to melillite, from $\mathrm{S}$. Characterization of $\mathrm{G}$ and $\mathrm{S}$ through FTIR techniques can be seen in Figure $2 b$.
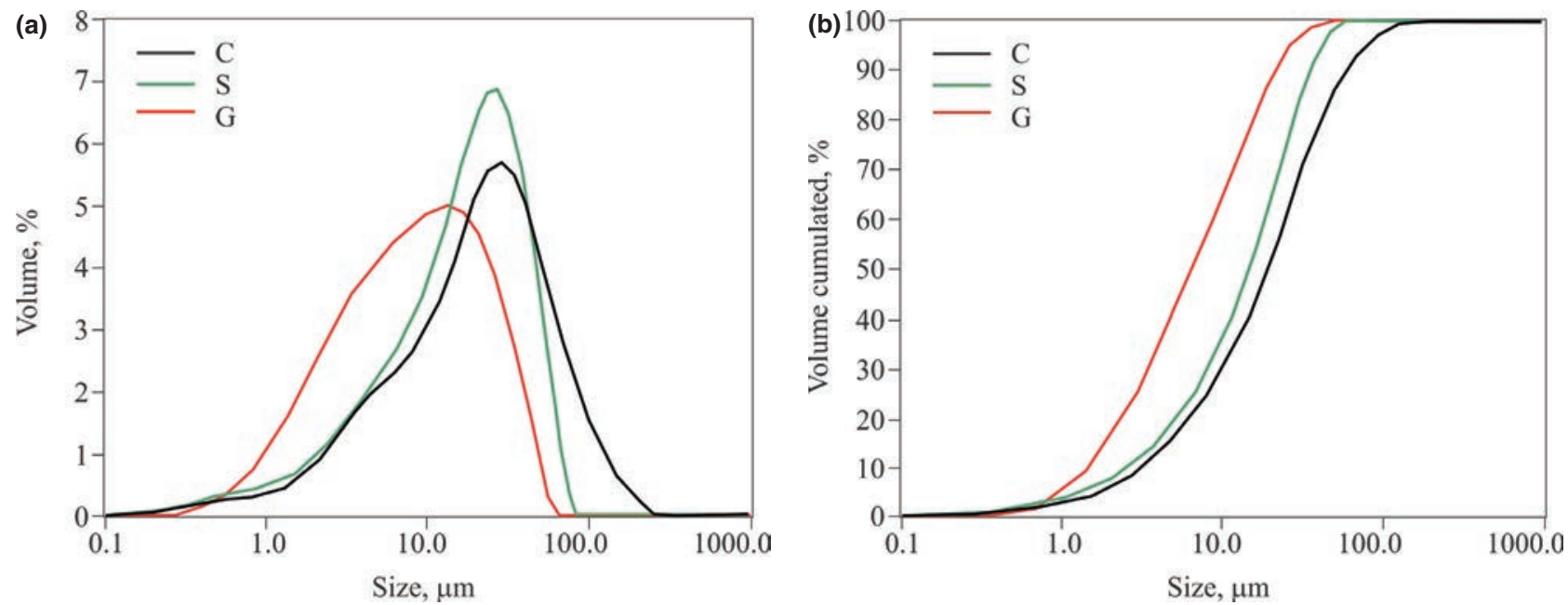

FIGURE 1. Particle size distribution a) partial, b) cumulated.
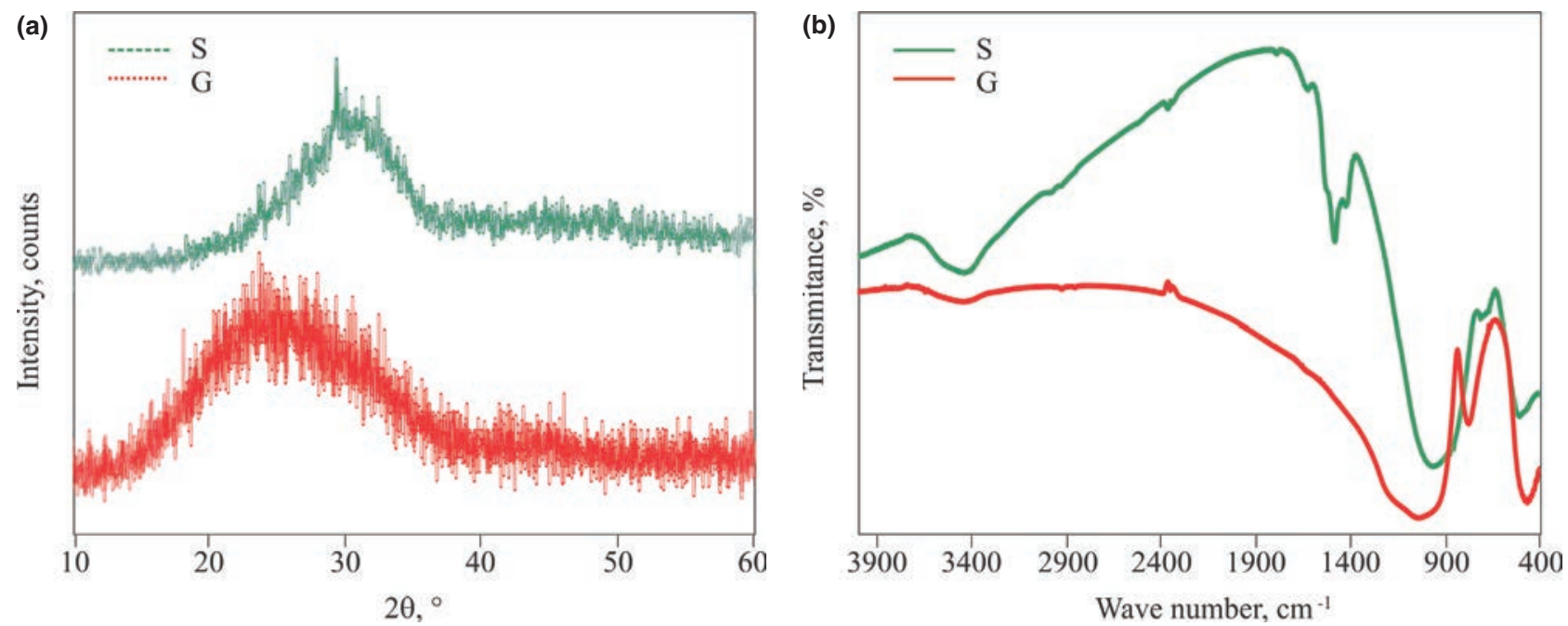

FIGURE 2. a) DRX and b) FTIR spectra of $G$ and $S$. 
FTIR spectra of S show a broad band in $962 \mathrm{~cm}^{-1}$ characteristic of asymmetric stretching vibration bands of Si-O in the silicate tetrahedrons, broadening and shifted to lower frequency, typical of IR spectra of glass phases (13). Vibration bands in $508 \mathrm{~cm}^{-1}$ are assigned to deformation vibration of silicate $\mathrm{O}-\mathrm{Si}-\mathrm{O}$ and the other between $600-800 \mathrm{~cm}^{-1}$ at asymmetric stretching vibration of $\mathrm{Al}-\mathrm{O}$ bonds of $\mathrm{AlO}_{4}$ (14). The bands near $1400 \mathrm{~cm}^{-1}$ were assigned to $\mathrm{CO}_{3}^{-2}$ group present by the partial carbonation of slag.

FTIR assignment of $\mathrm{G}$ is also performed on the basis of $\mathrm{SiO}_{4}^{4-}$ tetrahedron, which in this case has symmetry smaller than $\mathrm{Td}$. The $\mathrm{Si}-\mathrm{O}-\mathrm{Si}$ stretch vibration, coupled with other vibrators of the structure, is between: 700-1200 $\mathrm{cm}^{-1}$. The vibration of deformation O-Si-O is in the region $400-500 \mathrm{~cm}^{-1}$ (15).

TABLE 2. Identification of tested samples

\begin{tabular}{lccc}
\hline Blended cements & C (\%) & S (\%) & G (\%) \\
\hline C & 100 & 0 & 0 \\
CG10 & 90 & 0 & 10 \\
CG20 & 80 & 0 & 20 \\
CSG0 & 30 & 70 & 0 \\
CSG10 & 30 & 60 & 10 \\
CSG20 & 30 & 50 & 20 \\
CS-1 (NaOH solution 1\%) & 30 & 70 & 0 \\
CS-3 (NaOH solution 3\%) & 30 & 70 & 0 \\
CS-5 (NaOH solution 5\%) & 30 & 70 & 0 \\
\hline
\end{tabular}

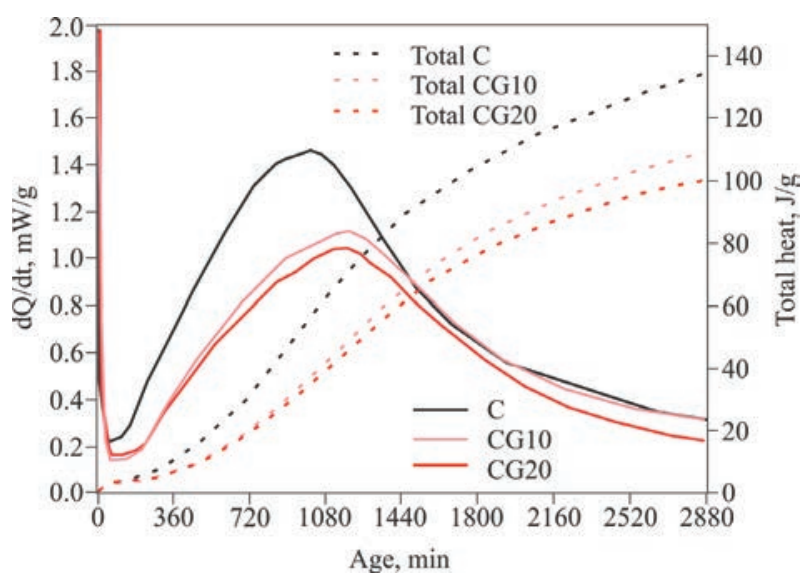

Figure 3. Heat release curves and total heat for C, CG10 and CG20.

\subsection{Mixtures and Test methods}

The reference slag blended cement was in proportion 30:70 (C:S) and then the $\mathrm{S}$ was replaced in 10 and $20 \%$ by mass with $\mathrm{G}$. Table 2 shows the name given to each sample and its composition. Slag cement, hydrated in the presence of $\mathrm{Na}(\mathrm{OH})$ solution, was used as comparison in order to establish the alkaline activation capacity of the ground glass at early age.

The rate of heat evolution and the cumulative heat released during early hydration (first 48 hours) of different pastes $(\mathrm{w} / \mathrm{b}=0.5)$ were registered by isothermal conduction calorimetry at $20^{\circ} \mathrm{C}$.

The workability of mortar was determined using the flow table test according to ASTM C1437 (16) as the diameters of spread mortar were measured along four lines and were expressed in percentage. Mortars were cast in $40 \times 40 \times 160 \mathrm{~mm}$ moulds and then compacted in two layers, covered with plastic sheet to prevent water loss and stored at $20 \pm 2{ }^{\circ} \mathrm{C}$. Standard siliceous sand and $\mathrm{w} / \mathrm{b}=0.50$ were used. After $24 \mathrm{~h}$, specimens were removed from the moulds and tightly covered with plastic sheets and stored until the test age was reached. From different blended cements, compressive strength was determined at 2, 7, 28 and 90 days. The reported results are the average of six compression tests.

The hydration of the pastes at 2, 7 and 28 days was analyzed by FTIR spectroscopy and the identification of hydration phases was carried out. Pozzolanic activity was determined by Frattini test according to the procedure described in EN196-5 at 2,7 and 28 days (17). This test evaluates the pozzolanic activity of blended cements measuring their reaction with the $\mathrm{Ca}(\mathrm{OH})_{2}$ released during cement hydration. The result is considered positive when the points are located below the calcium hydroxide solubility isotherm at $40{ }^{\circ} \mathrm{C}$.

\section{RESULTS}

\subsection{Heat released}

Figure 3 shows the heat release curves $(\mathrm{mW} / \mathrm{g})$ and the total heat $(\mathrm{J} / \mathrm{g})$ for $\mathrm{C}$ and blended cement pastes with addition of 10 and $20 \%$ powder glasses (CG10 and CG20). Table 3 shows information on singular points of the curves.

The rate of heat release declined and the intensity of the heat signal declined as the glass content grew.

TABLE 3. Singular points of heat hydration curves of C, CG10 and CG20

\begin{tabular}{|c|c|c|c|c|c|c|}
\hline \multirow[b]{2}{*}{ Blended cements } & \multicolumn{2}{|c|}{$1^{\text {st }}$ minimun } & \multicolumn{2}{|c|}{$2^{\text {nd }}$ peak } & \multicolumn{2}{|c|}{$3^{\text {rd }}$ peak } \\
\hline & Age, min & Int., mW/g & Age, min & Int., $\mathrm{mW} / \mathrm{g}$ & Age, min & Int., $\mathrm{mW} / \mathrm{g}$ \\
\hline $\mathrm{C}$ & 60 & 0.23 & 880 & 1.42 & 995 & 1.46 \\
\hline CG10 & 70 & 0.15 & 920 & 1.01 & 1160 & 1.11 \\
\hline CG20 & 80 & 0.18 & 890 & 0.91 & 1150 & 1.03 \\
\hline
\end{tabular}


An increase in the dormant period and a delay in the occurrence of the second and third peaks in approximately 180 minutes were also observed.

As a consequence, the total heat released in the first 48 hours of hydration was lower and corresponded to 82 and $75 \%$ of the $\mathrm{C}$ heat $(133.75 \mathrm{~J} / \mathrm{g})$ for the CG10 and CG20 blended cements, respectively.

Figure 4 shows the heat release curves $(\mathrm{mW} / \mathrm{g})$ and the total heat $(\mathrm{J} / \mathrm{g})$ for CSG0 and blended cement pastes with addition of 10 and $20 \%$ powder glasses (CSG10 and CSG20). Table 4 shows information on singular points of the curves.

Replacement of cement by $70 \%$ slag (CSG0) produced a general reduction of the heat release and extended the dormant period, generating a total heat equivalent to $35 \%$ of the reference $\mathrm{C}(133.75 \mathrm{~J} / \mathrm{g})$ at 48 hours of hydration. (Figure 4)

When the slag was replaced with 10 and $20 \%$ ground glass (CSG10 and CSG20), there were no significant differences in the dormant period compared to CSG0; but the intensity of the main peak increased (from 0.39 for CSG0 to 0.50 and $0.47 \mathrm{~mW} / \mathrm{g}$ for CGS10 and CGS20, respectively).

The total heat release in the first 48 hours for CGS10 and CGS20 was the same and $45 \%$ of the total heat equivalent to $\mathrm{C}(133.75 \mathrm{~J} / \mathrm{g})$.

In Figure 5, the heat release velocity curves of blending cement with $70 \%$ replacement with $\mathrm{S}$ (CSG0) are shown. These samples were hydrated

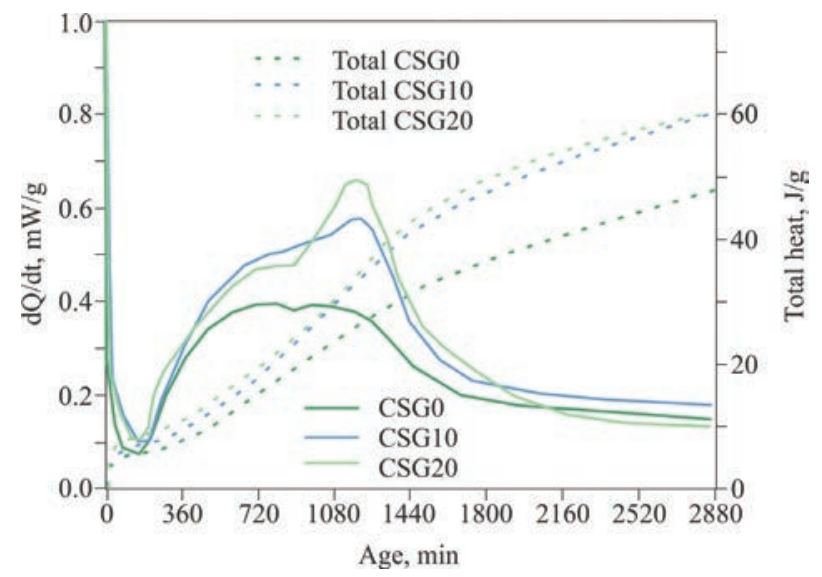

FIgURE 4. Heat release rate and total heat for CSG0, CSG10 and CSG20. with $\mathrm{NaOH}$ solutions at different concentrations: 1,3 and $5 \%$ (CS-1, CS-3 and CS-5 respectively). Table 5 shows the singular points of hydration curves.

The maximum intensity peak increased between 1 and $3 \% \mathrm{NaOH}$ and it decreased between 3 and 5\% $\mathrm{NaOH}$. Therefore, in the first 48 hours of hydration the sample with $3 \% \mathrm{NaOH}$ generated the highest heat of hydration $(52.35 \mathrm{~J} / \mathrm{g})$. This value was $9.5 \%$ higher than that of blended cement (CSG0) hydrated with water and $\sim 13.5 \%$ lower than those with 10 and $20 \%$ ground glass (CSG10 and CSG20) and with a considerable reduction of the dormant period, in agreement with the already reported results $(18,19)$.

\subsection{Flow and compressive strength}

For different mortars, the results of the flow test (in \%) are shown in Table 6. Fluidity of mortars CG10 and CG20 was less than that of C. When incorporating 10 and 20\% glass (CSG10 and CSG20) in slag cement, the percentage of slag was reduced and the effect tended to be reversed. The use of $3 \% \mathrm{NaOH}$ solution slightly reduced the fluidity compared to that of $\mathrm{C}$, but it improved considerably with respect to CSG0.

Figure 6 shows the results of compressive strength of mortars in MPa. The compressive strength grew with age for all samples.

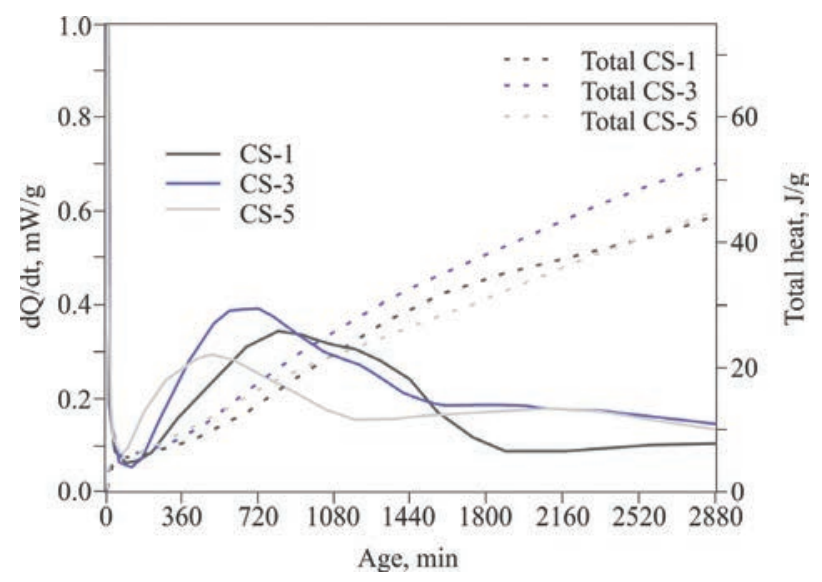

Figure 5. Heat release rate and total heat for CS-1, CS-3 and CS-5.

TABLE 4. Singular points of heat hydration curves of CSG0, CSG10 and CSG20

\begin{tabular}{|c|c|c|c|c|c|c|}
\hline \multirow[b]{2}{*}{ Blended cements } & \multicolumn{2}{|c|}{$1^{\text {st }}$ minimum } & \multicolumn{2}{|c|}{$2^{\text {nd }}$ peak } & \multicolumn{2}{|c|}{$3^{\text {rd }}$ peak } \\
\hline & Age min & Int., mW/g & Age, min & Int., $\mathrm{mW} / \mathrm{g}$ & Age, min & Int., $\mathrm{mW} / \mathrm{g}$ \\
\hline CSG0 & 160 & 0.10 & 810 & 0.39 & 1020 & 0.38 \\
\hline CSG10 & 160 & 0.12 & 800 & 0.50 & 1170 & 0.57 \\
\hline CSG20 & 170 & 0.11 & 800 & 0.47 & 1170 & 0.65 \\
\hline
\end{tabular}


TABLE 5. Singular points of heat hydration curves of CS hydrated with $\mathrm{NaOH}$ solution

\begin{tabular}{|c|c|c|c|c|c|c|}
\hline \multirow[b]{2}{*}{ Blended cements } & \multicolumn{2}{|c|}{$1^{\text {st }}$ minimum } & \multicolumn{2}{|c|}{$2^{\text {nd }}$ peak } & \multicolumn{2}{|c|}{$3^{\text {rd }}$ peak } \\
\hline & Age, min & Int., mW/g & Age, min & Int., $\mathrm{mW} / \mathrm{g}$ & Age, min & Int., mW/g \\
\hline CS-1 & 125 & 0.13 & 860 & 0.38 & 1200 & 0.35 \\
\hline $\mathrm{CS}-3$ & 115 & 0.10 & 680 & 0.42 & 1100 & 0.34 \\
\hline CS-5 & 80 & 0.14 & 490 & 0.33 & 700 & 0.30 \\
\hline
\end{tabular}

TABLE 6. Flow of mortars (\%)

\begin{tabular}{lcccccc}
\hline C & CG10 & CG20 & CSG0 & CSG10 & CSG20 & CS-3 \\
\hline 127.5 & 82.0 & 82.0 & 45.0 & 66.2 & 66.3 & 125.0 \\
\hline
\end{tabular}

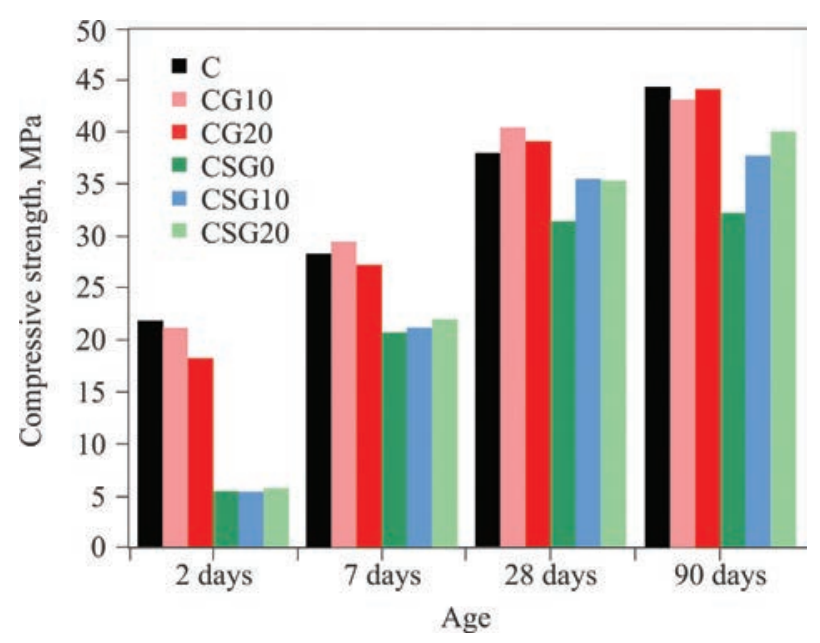

FIGURE 6. Compressive strength.

At 2 days, the compressive strength of CG10 and CG20 mortars was less than $\mathrm{C}$, but these samples contained less cement than the reference sample. The compressive strength of CG10 and CG20 at 7 and 28 days reached or exceeded $\mathrm{C}$ at the same ages. The effect was moderated at 90 days.

At 2 days, CSG0, CSG10 and CSG20 mortars showed the effect of dilution on their compressive strength values. At 7 days, there was a considerable increase in the compressive strength overcoming the dilution; all mortars had a compressive strength greater than $70 \%$ of the pattern (C). At 28 days, although the CSG0 mortar reached $82.5 \%$ of the compressive strength of the pattern (C); CSG10 and CSG20 mortars reached $93 \%$ of the pattern. This means approximately 13\% above CSG0 due to the joint action of slag and ground glass. Table 7 summarizes the previous information and shows the evolution of the compressive strength with the age of the samples studied, compared with the reference. At 90 days the same trend continued and compressive strength increased with the percentage of $\mathrm{G}$.

\subsection{Moritoring of hydration}

The study of hydration and the identification of the phases formed were carried out by FTIR on pastes at different ages. The main vibrational bands identified for hydrated blended cements were: the wide bands located between $3450-3300 \mathrm{~cm}^{-1}$, and $1640 \mathrm{~cm}^{-1}$ corresponded to the stretching and bending vibrations respectively of the $\mathrm{O}-\mathrm{H}$ bond in the water (6). The phases associated with hydrated calcium aluminates (which had bound water) could be analyzed in this area. Thus, in the samples with slag (with and without glass), these bands became wider as a consequence of the alumina of slag, since cement has a low $\mathrm{C}_{3} \mathrm{~A}$ content.

The peak in $3645 \mathrm{~cm}^{-1}$ was attributed to the $\mathrm{O}-\mathrm{H}$ bond of $\mathrm{CH}$ (20). The $\mathrm{SiO}_{4}$ groups in the anhydrous materials (cement and slag) shifted to $996 \mathrm{~cm}^{-1}$ with the hydration age in the pastes (v3 Si-O bond) due to the formation of calcium silicate hydrate (C-S-H) and calcium aluminosilicate hydrate (C-A-S-H) (21). The advancement of hydration was related to with the shift and widening of these bands.

The band at $460 \mathrm{~cm}^{-1}$ and the signal at $669 \mathrm{~cm}^{-1}$ were attributed to $v 2$ and $v 4$ (Si-O-Si) bond vibrations, respectively. Another significant band was at $1420 \mathrm{~cm}^{-1}$, attributed to $v 3 ; \mathrm{CO}_{3}{ }^{2-}$ and the band detected in 872 and $713 \mathrm{~cm}^{-1}$ were associated with $v 2, \mathrm{CO}_{3}^{2-}$ and $v 4, \mathrm{CO}_{3}^{2-}$, respectively $(22,23)$. These vibrations were characteristic of calcite present as a minor component of cement and by pastes carbonation.

Figure 7 shows the infrared spectra of C, CG20, CSG0 and CSG20 at 2, 7 and 28 days of hydration. It can be seen that the silicate bands moved to a greater number of waves in all cases. The peak assigned to the $\mathrm{CH}\left(3645 \mathrm{~cm}^{-1}\right)$ appeared in the CG20 in the first ages and, as age increased, its intensity decreased. This peak is absent in CSG0 and CSG20 from the 2 days.

\subsection{Pozzolanic activity}

Figure 8 shows the pozzolanicity results of blended cements obtained by the standard Frattini test. The samples tested were CG10 CG20, CSG0, CSG10 and CSG20 at 2, 7 and 28 days. 
TABLE 7. Compressive strength relative to the reference

\begin{tabular}{|c|c|c|c|c|c|c|}
\hline \multirow[b]{3}{*}{ Bended cements } & \multicolumn{6}{|c|}{ Compressive strength relative } \\
\hline & \multicolumn{3}{|c|}{ Reference C } & \multicolumn{3}{|c|}{ Reference CSG0 } \\
\hline & 2 days & 7 days & 28 days & 2 days & 7 days & 28 days \\
\hline CSG0 & 24.6 & 73.1 & 82.5 & 100.0 & 100.0 & 100.0 \\
\hline CSG10 & 24.6 & 74.9 & 93.2 & 100.0 & 102.4 & 113.1 \\
\hline CSG20 & 26.0 & 77.5 & 92.9 & 105.7 & 106.1 & 112.7 \\
\hline
\end{tabular}
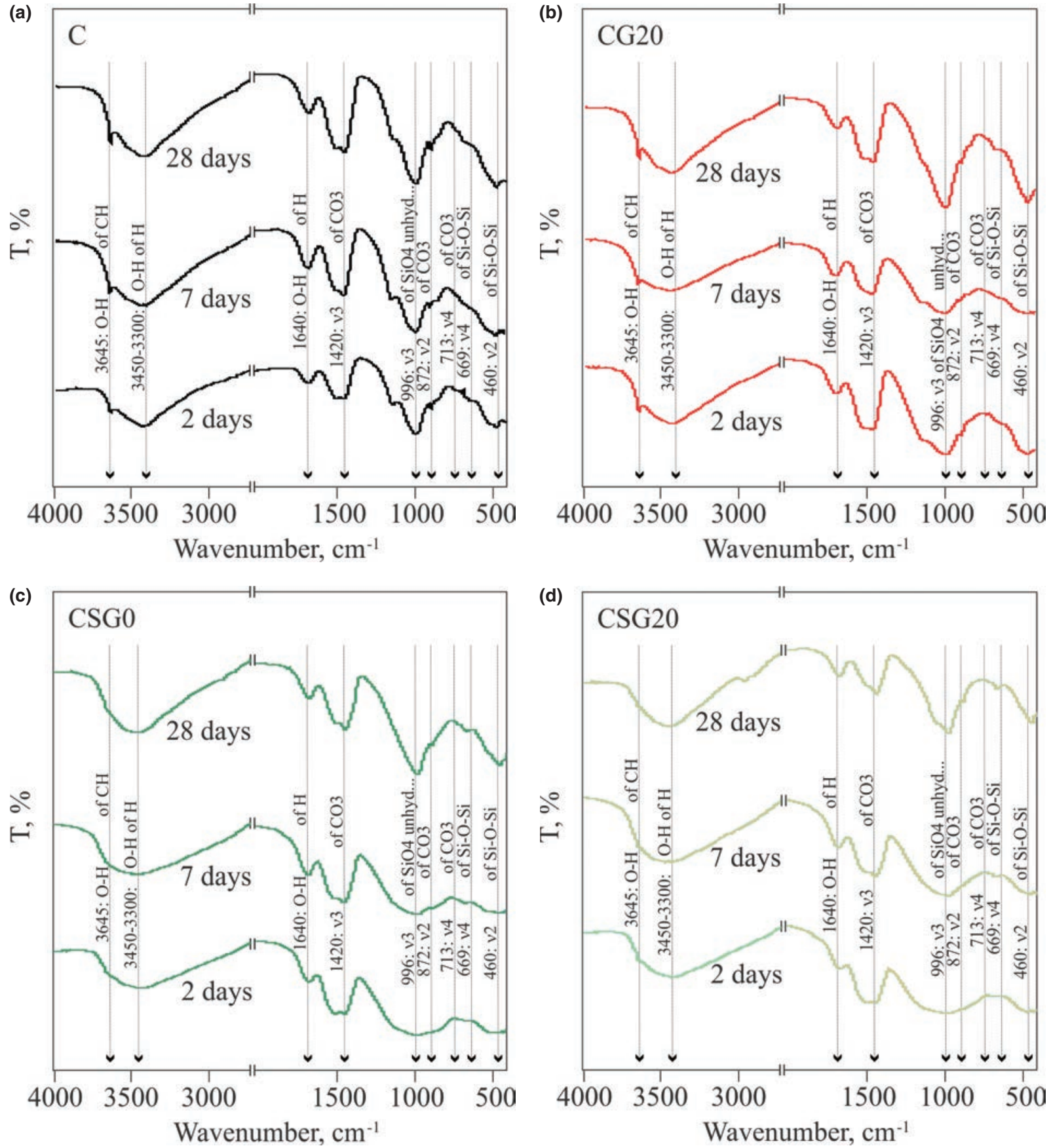

FIGURE 7. FTIR spectra of: a) C, b) CG20, c) CSG0 and d) CSG20 at 2, 7 and 28 days. 


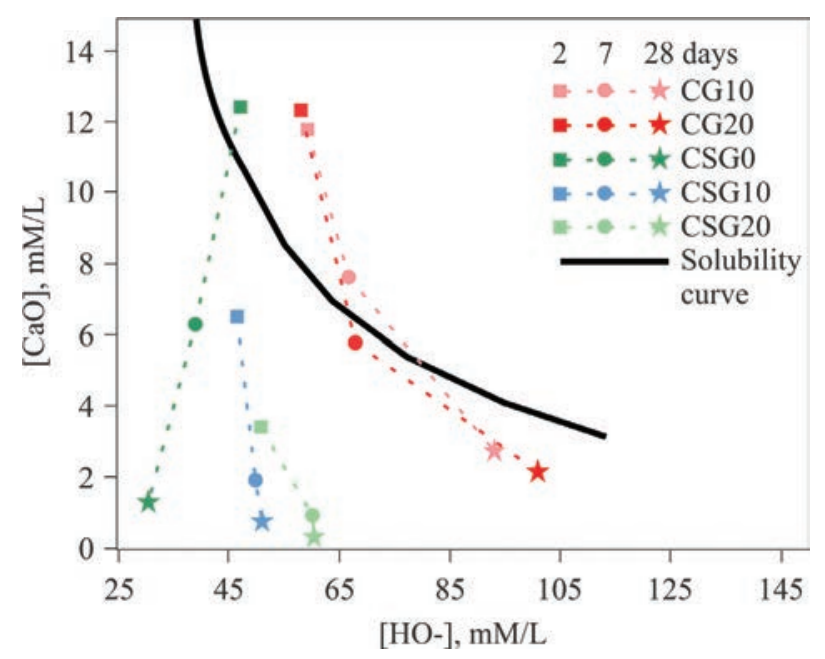

FIgURE 8. Frattini test at 2, 7 and 28 days.

For CG10 and CG20 at 2 days, there was stimulation by $\mathrm{G}$ because the values of $(\mathrm{CaO}]$ and $\left[\mathrm{OH}^{-}\right]$resulted in the same order despite the increase in the percentage of replacement. At 7 and 28 days, the pozzolanic reaction occured due to the decrease in $[\mathrm{CaO}]$. However, $\left[\mathrm{OH}^{-}\right]$increased instead of decreasing with $[\mathrm{CaO}]$, by the alkalis release by $\mathrm{G}$.

For CSG0, stimulation was observed at 2 days and pozzolanic activity at 7 and 28 days by simultaneously decreasing $[\mathrm{CaO}]$ and $\left[\mathrm{OH}^{-}\right]$. For CSG10 and CSG20 samples, pozzolanic activity was observed at 2 days by decreasing $[\mathrm{CaO}$ ] with the increase of the percentage of $\mathrm{G}$ replacement. However, $\left[\mathrm{OH}^{-}\right]$ increased slightly (much less than for samples CG10 and CG20) despite it had the same content of $\mathrm{G}$. Alkaline activation of slag by ground glass in CSG10 and CSG20 could be observed by the significant decrease of $\left[\mathrm{OH}^{-}\right]$compared with those released in CG10 and CG20.

\section{DISCUSSION}

At early age, the incorporation of $\mathrm{G}$ as partial replacement of $\mathrm{C}$ modifies the initial hydration reactions. By isothermal conduction calorimetry it was observed that, the total heat released in the first 48 hours of hydration was lower than $\mathrm{C}$ heat $(133.75 \mathrm{~J} / \mathrm{g})$ and corresponded to 82 and $75 \%$ for CG10 and CG20, respectively. It was expected due to the dilution generated by the addition and to the higher effective w/c ratio $(0.50,0.55$ and 0.625 for $\mathrm{C}$, CG10 and CG20, respectively).

The incorporation of $\mathrm{G}$ to CSG0 accelerates and stimulates the reactions, advancing the appearance of the third maximum and increasing its intensity. This maximum appeared at around 1170 minutes (19.5 hours) with intensities of 0.57 and $0.65 \mathrm{~mW} / \mathrm{g}$ for CGS10 and CGS20, respectively. This shows the effect of stimulation of $\mathrm{G}$, especially of the aluminum fraction of the slag when the main peak is split, since the first corresponds to the hydration of the silicates and the second to that of the aluminates (24). This effect can be interpreted as a selective stimulation of glass powder on the aluminum phase of slag since cement is a minor component and it has a low content of $\mathrm{C}_{3} \mathrm{~A}$.

Hydration with $\mathrm{NaOH}$ solution generally shows an acceleration of the reactions as the concentration increases. Shi et al (18) found that the initial $\mathrm{pH}$ of the activator solution has an important role in dissolving the slag and in promoting the early formation of some hydration products; in all cases decreasing the time when the dormant period occurs and when the maximum appears. The results obtained for the hydration of CSG0 in this study are consistent with those reported.

Fluidity of mortars CG10 and CG20 was less than that of $\mathrm{C}$. This behavior may be due in part to the fact that glass particles replacing those of cement have greater fineness and lower density. Thus, there are a greater total number of particles (see Table 1) which need more water to wet all surfaces. In slag mortars a similar event occurs, but it is exacerbated by the high percentage of replacement and the absorption of $\mathrm{S}$ (see Table 1). However, the replacement of $S$ with $G$ improves the fluidity of the mortars.

In hard state, at 2 and 7 days, compressive strength of CG10 and CG20 mortars showed that the stimulation effect generated by the addition compensates and overcomes the dilution generated by the replacement. By this stimulation the compressive strength of CG10 and CG20 at 28 days exceeds that reached by $\mathrm{C}$ at the same age. This effect can be attributed to the pozzolanic reaction of the glass (see Figure 8), the presence of more nucleation sites for cement hydration products and the greater packing achieved by mixtures since glass has smaller particles than those of the cement.

At 2 days CSG0, CSG10 and CSG20 mortars show the effect of dilution on their compressive strength values; this is deepened due to the increase of the effective $\mathrm{w} / \mathrm{c}$ ratio that changes from 0.5 to the standard to 1.66 for mortars with slag and with slagglass. A 7 days, there was a considerable increase in the compressive strength overcoming the dilution; all mortars had a compressive strength greater than $70 \%$ of the pattern $(\mathrm{C})$. This effect can be attributed to the best packaging by the incorporation of particles of sizes smaller than cement (see table 1), to the auto-pozzolanic reaction of slag and pozzolanic of glass (see Figure 8) and confirmed by FTIR.

Finally, at 28 days, although the CSG0 mortar reached $82.5 \%$ of the compressive strength of the pattern (C), CSG10 and CSG20 mortars reached $93 \%$ of the pattern, approximately $13 \%$ above the compressive strength of CSG0. This fact may be due to an additional stimulation of glass on slag 
as a natural alkaline activation and its synergy. In the same way, at 90 days, compressive strength increases with the increase of the percentage of incorporated glass. This effect can be also followed by FTIR, through the intensity decreasing of the $3645 \mathrm{~cm}^{-1}$ peak and the continuous widening of the silicate band. The absence of the peak of $3645 \mathrm{~cm}^{-1}$ in CSG0 and CSG20 at any age shows the complete consumption of $\mathrm{CH}$ generated by the hydration of cement by the combined action of $\mathrm{G}$ and $\mathrm{S}$, which results in a greater compressive strength.

\section{CONCLUSION}

It can be concluded that the incorporation of ground glass into the slag cement at early age stimulated the reactivity of silicates and aluminum phases of the slag and it also improved the flow of mortars. After 7 days, compressive strength exceeded dilution due to the combined auto- pozzolanic and pozzolanic action of slag and glass, respectively. Ground glass powders have good pozzolanic properties and can be used as cement replacement in cements mixed with slag. The presence of glass powder improves compressive strength of slag cement and it is attributed to the alkali released by $\mathrm{G}$.

\section{ACKNOWLEDGMENTS}

The authors gratefully acknowledge the financial support from the FONCYT, MINCYT Argentina under project PICT 2012-0160.

\section{REFERENCES}

1. Li, C.; Sun, H.; Li, L. (2010) A review: The comparison between alkali-activated slag $(\mathrm{Si}+\mathrm{Ca})$ and metakaolin (Si+Al) cements. Cem. Concr. Res. 40, 1341-1349. https:// doi.org/10.1016/j.cemconres.2010.03.020

2. Menendez, G.; Bonavetti, V.L., Irassar, E.F. (2003) Strength development of ternary blended cement with limestone filler and blast-furnace slag, Cem. Concr. Compos. 25 [1] 57-63. https://doi.org/10.1016/S0958-9465(01)00056-7

3. Castellano, C.C.; Bonavetti, V.L.; Donza, H.A.; Irassar, E.F. (2016) The effect of w/b and temperature on the hydration and strength of blastfurnace slag cements, Constr. Build. Mater. 111, 679-688. https://doi.org/10.1016/j.conbuildmat.2015.11.001

4. García-Lodeiro, I.; Maltseva, O.; Palomo, A.; FernándezJiménez, A. (2012) Hybrid alkaline cements. Part I: fundamentals, Rom. J. Mater. 42 [4] 330-335.

5. Palomo, A.; Maltseva, O.; Garcia Lodeiro, I.; Fernandez Jimenez, A. (2013) Hybrid alkaline cements. Part II: the clinker factor, Rom. J. Mater. 43 [1] 74-80.

6. Angulo-Ramírez, D.E.; Mejía de Gutiérrez, R.; F. Puertas, (2017) Alkali-activated Portland blast-furnace slag cement: Mechanical properties and hydration, Constr. Build. Mater. 140, 119-128. https://doi.org/10.1016/j. conbuildmat.2017.02.092
7. Palomo Tomás, V.; Reciclar vidrio es ahorrar combustible. Available online: http://www.justoysustentable. org/2012/04/reciclar-vidrio-es-ahorrar-combustible.html. Acceded 24/06/2016.

8. Shi, C.; Zheng, K.; (2007) A review on the use of waste glasses in the production of cement and concrete, Resour. Conserv. Recyc. 52 [2] 234-247. https://doi.org/10.1016/j. resconrec.2007.01.013

9. Trezza, M.A; Rahhal, V.F. (2018) Behavior of the ground glass waste in blending cements: Comparative study with microsilice. Materia 23 [1]. https://doi.org/10.1590/ s1517-707620170001.0311

10. Federico, L.M.; Chidiac, S.E. (2007) Waste glass as a supplementary cementitious material in concrete - Critical review of treatment methods, Cem. Concr. Compos. 31, 306-310. https://doi.org/10.1016/j.cemconcomp.2009.02.001

11. Zhang, S.; Keulen, A.; Arbi, K.; Ye Zhang, G. (2017) Waste glass as partial mineral precursor in alkali-activated slag/ fly ash system. Cem. Concr. Res. 102, 29-40. https://doi. org/10.1016/j.cemconres.2017.08.012

12. Marchetti, G.; Rahhal, V.F.; Irassar, E.F. (2017) Influence of packing density and water film thickness on earlyage properties of cement pastes with limestone filler and metakaolin. Mat. Struct. 50 [2] 111. https://doi. org/10.1617\%2Fs11527-016-0979-1

13. Mostafá, N.Y; El-Hernaly S.A.S; Al-Wakeel, E.I; El-Korashy, S.A.; Brown, P.W. (2001) Characterization and evaluation of the hydraulic activity of water-cooled slag and air- cooled slag. Cem. Concr. Res. 31[6], 899-904. https://doi.org/10.1016/S0008-8846(01)00497-5

14. Torres-Carrasco, M.; Rodriguez-Puertas, C.; Alonso, M.M. (2015) Alkali activated slag cements using waste glass as alternative activators. Rheological behaviour. Bol. Soc. Esp. Ceram. Vidr. 54, 45-57. https://doi.org/10.1016/j. bsecv.2015.03.004

15. Bensted, J.; Varma, S.P. (1974) Some applications of infrared and Raman spectroscopy in cement chemistry. Part I- Examination of dicalcium silicate. Cement Technology, 256-261.

16. ASTM C1437-15, Standard Test Method for Flow of Hydraulic Cement Mortar

17. EN 196-5: Cements Test Methods: Pozzolanic test for Pozzolanic cements (in Spanish)

18. Shi, C.; Day, R. (1995). A calorimetric study of early hydration of alkali-slag cement, Cem. Concr. Res. 25 [6] 1333-1346. https://doi.org/10.1016/0008-8846(95)00126-W

19. Bakharev, T.; Sanjayan, J.; Cheng, Y-B. (1999) Álkali activation of Australian slag cements, Cem. Concr. Res. 29, 113-120. https://doi.org/10.1016/S0008-8846(98)00170-7

20. Mollah, M.Y.A.; Yu, W.; Schennach, R.; Cocke, D. (2000) A Fourier transforms infrared spectroscopic investigation of the early hydration of Portland cement and the influence of sodium lignosulfonate. Cem. Concr.Res. 30, 267-273. https://doi.org/10.1016/S0008-8846(99)00243-4

21. Puertas, F.; Torres-Carrasco, M. (2014) Use of glass waste as an activator in the preparation of alkali-activated slag. Mechanical strength and paste characterization. Cem. Concr. Res. 57, 95-104. https://doi.org/10.1016/j. cemconres.2013.12.005

22. Farcas, F.; Touzé, P. (2001) Infrared Fourier Transform (IRFT) spectrometry. A valuable technique for characterizing cement. Bulletin des Laboratories des Ponts et Chaussées. 230 [4350] 77-88.

23. Bensted, J.; Varma, S.P. (1977), Infrared and Raman spectroscopy in cement chemistry-miscellaneous applications. World Cement Technology 8 [1] 16, 18-20.

24. Mindess, S.; Young, J.F. (1981) Concrete, Cap.4. PrenticeHall, New Jersey, 1981. 